\title{
THE INFLUENCE OF ABSORTIVE CAPACITY AND KNOWLEGDE SHARING ON WOMEN-OWNED SMEs
}

\author{
${ }^{1}$ Hendra Hadiwijaya, ${ }^{2}$ Febrianty \\ Email: ${ }^{1}$ hendra_hadi@palcomtech.ac.id, ${ }^{2}$ febrianty@palcomtech.ac.id \\ ${ }^{12}$ Palcomtech Polytechnic
}

DOI: 10.29322/IJSRP.8.6.2018.p7851

http://dx.doi.org/10.29322/IJSRP.8.6.2018.p7851

\begin{abstract}
This study aimed to determine the effect of Absorptive Capacity and Knowledge Sharing on the performance of womenowned SMEs group. The sample of this research was female business actor who joined in Alisah Khadijah group of ICMI Palembang as many as 138 business actors. Analysis of this research used Structural Equation Modeling (SEM) program with Lisrel Program. The result showed that Absorptive Capacity and Knowledge Sharing variable had positive and significant influence on Performance of SME group incorporated in Alisah Khadijah ICMI Palembang. Absorptive Capacity variable had more dominant influence on Performance than Knowledge Sharing variable.
\end{abstract}

Index Term- Absorptive Capacity, Knowledge Sharing, Performance, UKM

\section{Introduction}

Sources of external knowledge are essential in innovation, meaning the ability to utilize external knowledge is a critical component of innovative capabilities. An organization needs related knowledge before assimilating and using new knowledge called absorptive capacity (Cohen \& Levinthal, 1990). Previous learning experiences may affect subsequent performance. Absorptive capacity according to (Zahra \& George, 2002) is a set of routines and organizational processes, so as to acquire, assimilate, transform, and exploit knowledge to produce dynamic organizational capabilities. Absorptive capacity is so important that companies can do something very different, be able to identify, and exploit the easy and rapidly changing business opportunities.

Knowledge sharing as a basic means is: employees or organization can exchange knowledge and contribute to knowledge, innovation, and ultimately to an organization's competitive advantage (Wang \& A. Noe, 2010). Knowledge sharing effort is a central process of Knowledge Management, which can improve innovation performance and reduce excessive costs in learning (Calantonea, Cavusgil, \& Zhao, 2002; Matzler \& Mueller, 2011). Knowledge sharing ability can be categorized into three dimensions, namely willingness to share knowledge, ability to learn, and ability to transfer knowledge (Mathuramaytha, 2012). Organization at the operational stage needs to stimulate and increase knowledge capital and provide its employees with adequate means to communicate and share information (Nonaka \& Takaeuchi, 1995). The dimension of knowledge sharing adopted is by (B. van den Hooff \& Weenen, 2004), consisting of two dimensions: a). Knowledge donating is the process of donating knowledge by leaders, employees, and others, b). Knowledge collecting is the process of seeking knowledge by leaders and employees of others.

Performance is the result or success rate of a person or organization as a whole over a certain period, (Basri \& Rivai, 2005; Hadiwijaya, 2015). Furthermore (Hadiwijaya, 2015; Prawirosentono, 2001) suggested that performance is the result of work that can be achieved by a person or group of people within an organization in accordance with their respective responsibilities, in order to attempt to achieve the organization's objectives legally, with morals and ethics. Various criteria are used in performance measurement. Performance is the outcome or overall success rate over a given period compared to possible possibilities, such as predetermined or agreed work standards, predetermined targets or goals or criteria (Hadiwijaya, 2017; Mathis \& Jackson, 2006).

This study took the phenomenon of female business actor group incorporated in ALISA Khadijah which is the Association of Muslim Entrepreneurs in Indonesia was established by the Department of Women's Role Development (DPPW) ICMI Center. Alisa Khadijah is an organization under ICMI (Association of Indonesian Muslim Intellectuals), who was inaugurated by Mr. Bacharuddin Jusuf Habibie over the pioneer of his wife Alm. Hasri Ainun Habibie whose initial goal was to gather entrepreneurs who are expected to be able to create jobs for unemployment. ALISA Khadijah's vision is to become a Muslim entrepreneur organization that synergizes entrepreneurial potential for the realization of a prosperous society. Researchers were interested to raise the extent of the absorptive capacity and Knowledge Sharing process that occurs in women entrepreneurs who are members of the group and the impact on business performance. 
The research by (Andrawina, Govindaraju, Samadhi, \& Sudirman, 2008) on the Relationship between Knowledge Sharing Capability, Absorptive Capacity, and Formal Mechanism: Case Study of Information and Communication Technology Industry in Indonesia. The results showed that knowledge sharing capability had a significant effect on potential absorptive capacity, the ability of companies to acquire and assimilate significantly influence the ability to transform and exploit knowledge. The relationship between potential absorptive capacity and realized absorptive capacity was moderated by formal mechanisms. Another study that discusses the benefits of action groups on improving the performance of SMEs was performed by (Febrianty \& Divianto, 2017) entitled "The Influence Of Entrepreneurial Action Group On The SMEs Performance Through Internalization Of Quadruple Helix Innovation Role". The findings reveal that: a. There is a significant influence of Entrepreneurial Action Group on Creative Economybased SMEs Performance, b. There is a significant influence of Entrepreneurial Action Group over the Creative Economy-Based Internalization of Quadruple Helix Innovation Role, c. There is no influence of the Internalization of Quadruple Helix Innovation Role on Creative Economy-SMEs performance, d. There is a significant influence of Entrepreneurial Action Group and Internalization of Quadruple Helix Innovation Role on Creative Economy-Based SMEs performance. Increasing the performance of SMEs can be achieved by the implementation of coopetition, such as the results of research by (Febrianty, 2017) on the interests of SMEs in Choice for Application of Coopetition Strategy (Case Study: SMEs in Palembang City). The results showed there was a significant positive influence of attitudes, trust belief, and perceived risks simultaneously on the interest of choice for the implementation of coopetition strategy in SMEs in Palembang.

Based on the above description, the questions to be discussed are: how is the influence of Absorptive Capacity and Knowledge Sharing on the performance of women-owned SMEs group?

\section{Literature Review}

The concept of absorptive capacity was first introduced by Cohen and Levinthal (1990), they defined it as a company's ability to identify, assimilate, and exploit knowledge. Zahra and George (2002) reconceptualized absorptive capacity by proposing four dimensions: the ability to acquire, assimilate, transform, and exploit knowledge. Where 1 . Acquisition is the intensity of business and the speed of business actors in identifying and acquiring the knowledge needed for their operations activities sourced from the external environment, 2. Assimilation is the ability of business actors in assessing previous knowledge that has been owned, synthesize knowledge, and combine knowledge gained from external sources. 3. Transformation is the ability of business actors to develop and improve routines that facilitate the incorporation of existing knowledge with newly acquired knowledge, and 4. Exploitation is the ability of business actors to improve, extend, and elevate existing competencies/create new ones by combining knowledge obtained.

The absorptive capacity concept used in this study refers to Zahra and George (2002), which includes two things: potential absorptive capacity consists of the ability to acquire and assimilate and realize absorptive capacity consists of the ability to transform and exploit knowledge.

Hooff \& Ridder (2004) defined that knowledge sharing is the process by which individuals exchange their knowledge (tacit knowledge and explicit knowledge). This definition implies that any knowledge sharing behavior consisting of donating knowledge and collecting knowledge. Donating knowledge is a behavior of communicating the intellectual capital that one possesses to another while collecting knowledge is an individual's behavior to consult with other individuals about their own intellectual capital. Both of these behaviors have different properties and can have different effects/outcomes. Hooff and Weenen (2004) defined knowledge sharing as an activity of individuals to exchange personal intellectual capital.

\subsection{Research Population and Sample}

\section{Method}

The population in this study were Small and Medium Enterprises (SMEs) who are incorporated in Alisah Khadijah ICMI group of Palembang City of 209 business actors, all of whom are women. Due to the researcher's limitations, this study cannot be conducted on all populations, but some of the population represent it. Selection of respondents used Proportional Random Sampling method. By using the Slovin formula approach, (Umar, 2008):

$n=\frac{N}{1+N e^{2}}$

Where : $\quad \mathrm{n} \quad$ : Sample size

N : Population Size

e : Percentage of inaccuracy due to sampling error.

Where research data $\quad \mathrm{N}=209 \mathrm{e}=5 \%$

So the minimum number of sample that was taken: 


$$
\begin{aligned}
& n=\frac{209}{1+102(0.05)^{2}} \\
& n=137,27=\mathbf{1 3 8 \text { sample }}
\end{aligned}
$$

\subsection{Structural Equation Modelling (SEM) Analysis}

The analysis of this research used Structural Equation Modeling (SEM) program, which is operated through Lisrel Program. Another advantage of the SEM method is to simultaneously analyze multivariant. While the purpose of multivariate use is to expand the ability, in explaining the research and statistical efficiency (Ferdinand, A., 2005). The structural equation is expressed as follows:

\section{Endogenous Variable $=$ Exogenous Variable + Endogenous Variable + Error}

The goodness of fit index in this research by using SEM analysis method is as follows:

\begin{tabular}{|c|c|c|c|}
\hline No & Goodness of Fit Index & Cut off Value & Criteria \\
\hline \multirow[b]{2}{*}{1.} & Chi-Square & $<\boldsymbol{\alpha . d f}$ & \multirow{2}{*}{$\begin{array}{l}\text { Good Fit } \\
\text { Marginal fit }\end{array}$} \\
\hline & Probability & $\begin{array}{l}>0.05 \\
0.01-0.05\end{array}$ & \\
\hline 2. & RMSEA & $\begin{array}{l}\leq 0.08 \\
0.08-0.10\end{array}$ & $\begin{array}{l}\text { Good Fit } \\
\text { Marginal Fit }\end{array}$ \\
\hline 3. & NFI & $\begin{array}{l}\geq 0.90 \\
0.80-0.89\end{array}$ & $\begin{array}{l}\text { Good Fit } \\
\text { Marginal Fit }\end{array}$ \\
\hline 4. & NNFI & $\begin{array}{l}\geq 0.90 \\
0.80-0.89\end{array}$ & $\begin{array}{l}\text { Good Fit } \\
\text { Marginal Fit }\end{array}$ \\
\hline 5. & CFI & $\begin{array}{l}\geq 0.90 \\
0.80-0.89\end{array}$ & $\begin{array}{l}\text { Good Fit } \\
\text { Marginal Fit }\end{array}$ \\
\hline 6. & IFI & $\begin{array}{l}\geq 0.90 \\
0.80-0.89\end{array}$ & $\begin{array}{l}\text { Good Fit } \\
\text { Marginal Fit }\end{array}$ \\
\hline 7. & GFI & $\begin{array}{l}\geq 0.90 \\
0.80-0.89\end{array}$ & $\begin{array}{l}\text { Good Fit } \\
\text { Marginal Fit }\end{array}$ \\
\hline 8. & AGFI & $\begin{array}{l}\geq 0.90 \\
0.80-0.89\end{array}$ & $\begin{array}{l}\text { Good Fit } \\
\text { Marginal Fit }\end{array}$ \\
\hline
\end{tabular}

Table1. Goodness of Fit Index

Source: (Ferdinand, A., 2005)

\section{Result and Discussion}

\subsection{Confirmatory Factor Analysis (CFA)}

Confirmatory factor analysis (CFA) is designed to test the unidimensionality of a theoretical construct. This analysis is also often called to test the validity of a theoretical construct. To test the dimensional validity of the constructs in this study is performed by looking at the value of standard load factor of each indicator in the whole model (Full Model). The indicator is valid if it has a standard load factor which the value is greater than 0.5 and the level of received reliability is if the value of Construct Reliability $\geq$ 0.7 .

\section{a). Confirmatory Factor Analysis (CFA) of Exogenous Constructs}

Model measurements to test the validity of latent construct indicators were performed by looking at the standard load factor values of each indicator in the model. The CFA Model of Exogenous Constructs can be seen in Figure 1.: 


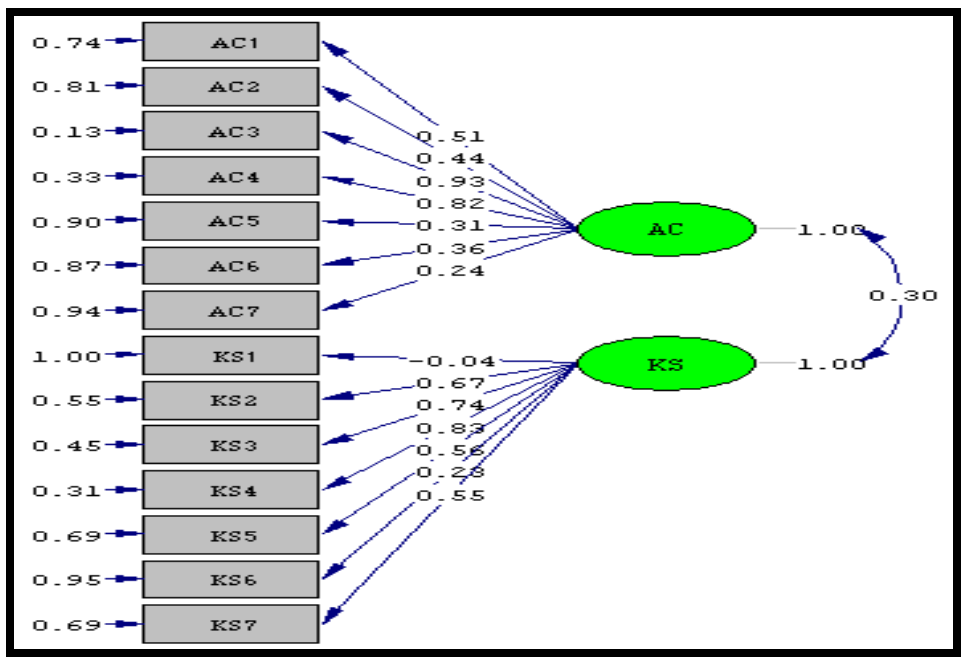

Figure 1. Model_1 CFA Exogenous Construct

Figure 1. shows the path diagram in CFA exogenous constructs model still had loading factor value less than 0.5, which is absorptive capacity variable (AC) on AC2, AC5, AC6 and AC7 indicator while Knowledge sharing (KS) on KS1, KS6, and KS7, meaning that the indicators were not yet valid and must be rejected, so that it was obtained Model_2 CFA Exogenous Constructs:

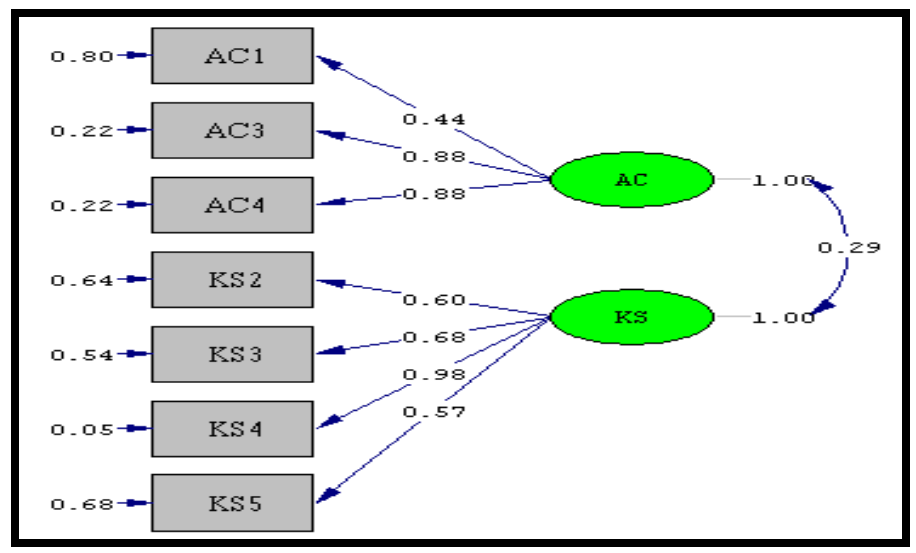

Figure 2. Model_2 CFA Exogenous Construct

Figure 2. shows the path diagram in Model_2 CFA Exogenous constructs which still had load factor value less than 0.5, which is the Absorptive capacity (AC) variable on the AC1 indicator, the indicator was still not valid and must be rejected, so that it was obtained Model_3 CFA Construct Exogenous:

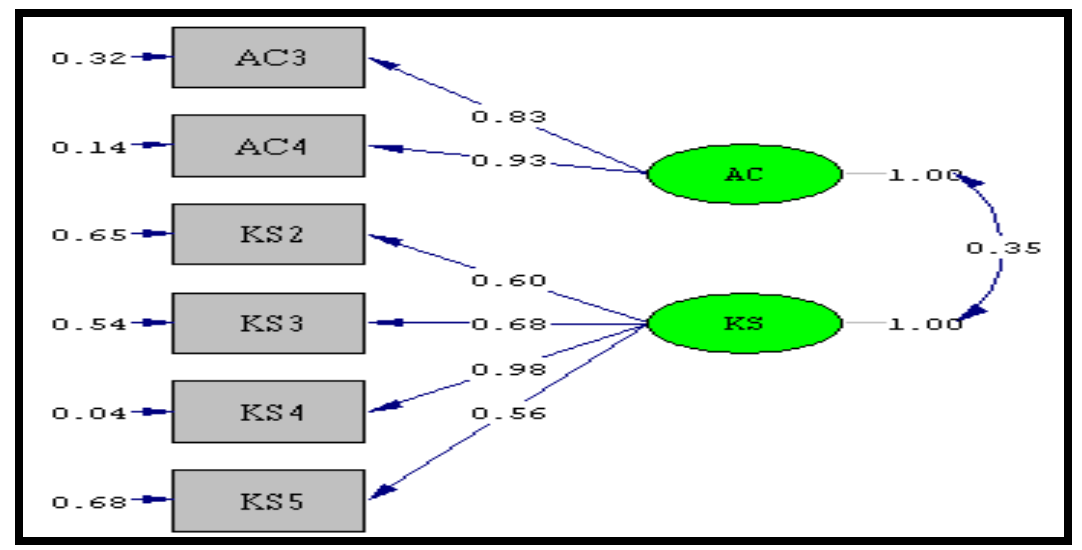

Figure 3. Model_3 CFA Exogenous Construct

Figure 3. indicates that the Model_3 CFA Exogenous Construct had no loading factor value less than 0.5 so that all the indicators on the variable Exogenous Absorptive capacity (AC) and Knowledge Sharing (KS) variables have been valid. The results of reliability calculations with Construct Reliability of Confirmatory Factor Analysis (Confirmatory Factor Analysis/CFA of endogenous variables) can be seen in Table 2 . 
Table 2. Validity and Reliability Test of Absorptive Capacity and Knowledge Sharing Variables

\begin{tabular}{|c|c|c|c|c|}
\hline Dimension & Indicator & $\lambda$ & Error $=1-\lambda^{2}$ & $\mathbf{C R}=\left(\sum \lambda\right)^{2} /\left(\left(\sum \lambda\right)^{2}+\sum\right.$ Error $)$ \\
\hline \multirow{2}{*}{$\begin{array}{c}\text { Absorptive Capacity } \\
\text { (AC) }\end{array}$} & AC3 & 0.83 & 0.32 & \multirow{2}{*}{0.871} \\
\hline & AC4 & 0.93 & 0.14 & \\
\hline \multirow{4}{*}{$\begin{array}{c}\text { Knowledge Sharing } \\
\text { (KS) }\end{array}$} & KS2 & 0.60 & 0.65 & \multirow{4}{*}{0.806} \\
\hline & KS3 & 0.68 & 0.54 & \\
\hline & KS4 & 0.98 & 0.04 & \\
\hline & KS5 & 0.56 & 0.68 & \\
\hline
\end{tabular}

Based on Table 2 it shows that the Construct Reliability (CR) value of all exogenous constructs was above 0.7 . Thus, it can be concluded that all dimensions and variables of research in Full Model have good reliability and validity.

\section{b). Confirmatory Factor Analysis (CFA) of Endogenous Construct}

CFA Model of Endogenous Construct can be seen in Figure 4:

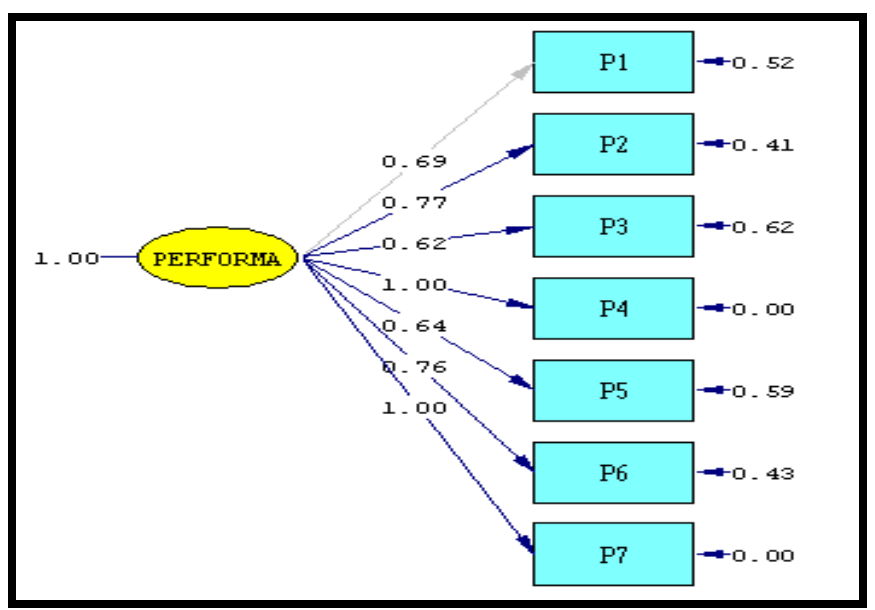

Figure 4. Model_1 CFA Endogenous Construct

Based on Figure 4, it indicates that in Model_1CFA Endogenous Construct, there was no loading factor value which is less than 0.5, so the indicator on the Endogenous variable has already been validated. The results of reliability calculations with Construct Reliability of Confirmatory Factor Analysis/CFA endogenous variables can be seen in Table 3.

Table 3. Validity and Reliability Test of Performance Variable

\begin{tabular}{c|c|c|c|c|}
\hline \multirow{2}{*}{ Dimensi } & Indicator & $\boldsymbol{\lambda}$ & Error $=\mathbf{1 -} \lambda^{2}$ & $\mathbf{C R}=\left(\sum \lambda\right)^{2} /\left(\left(\sum \lambda\right)^{2}+\sum\right.$ Error $)$ \\
\hline \multirow{4}{*}{ Performance } & P1 & 0.69 & 0.52 & \\
\cline { 2 - 5 } & P2 & 0.77 & 0.41 \\
\cline { 2 - 5 } & P3 & 0.62 & 0.62 \\
\cline { 2 - 5 } & P4 & 1.00 & 0.00 \\
\cline { 2 - 5 } & P5 & 0.64 & 0.59 \\
\cline { 2 - 4 } & P6 & 0.76 & 0.43 \\
\cline { 2 - 4 } & P7 & 1.00 & 0.00 \\
\hline
\end{tabular}

Based on Figure 4. and Table 3, it indicates that in Model_1 CFA Endogenous Construct there was no loading factor value which is less than 0.5 , indicating that all indicators on the endogenous variable (Performance) have been valid. While the value of 
Construct Reliability (CR) on Performance variables shows that of all exogenous constructs $>0.7$. Thus it can be concluded that all dimensions and variables Performance research in Full Model has good reliability.

\subsection{Structural Equation Modelling (SEM) Analysis}

Analysis of Structural Equation Modeling (SEM) in full model in testing the feasibility of the overall model was performed by observing the Goodness of Fit results that refer to the fit model criteria contained in Table 4. Goodness of Fit Index:

Table 4. Goodness of Fit Index

\begin{tabular}{|c|c|c|c|c|c|}
\hline \\
\hline No & $\begin{array}{l}\text { Goodness of Fit } \\
\text { Index }\end{array}$ & Value & Cut off Value & Criteria & Information \\
\hline \multirow[b]{2}{*}{1.} & Chi-Square & 320.46 & $<\boldsymbol{\alpha} . \mathrm{df}$ & \multirow{2}{*}{$\begin{array}{l}\text { Good Fit } \\
\text { Marginal fit }\end{array}$} & \multirow[b]{2}{*}{ Good Fit } \\
\hline & Probability & 0.015 & $\begin{array}{l}>0.05 \\
0.01-0.05\end{array}$ & & \\
\hline 2. & RMSEA & 0.019 & $\begin{array}{l}\leq 0.08 \\
0.08-0.10\end{array}$ & $\begin{array}{l}\text { Good Fit } \\
\text { Marginal Fit }\end{array}$ & Good Fit \\
\hline 3. & NFI & 0.92 & $\begin{array}{l}\geq 0.90 \\
0.80-0.89\end{array}$ & $\begin{array}{l}\text { Good Fit } \\
\text { Marginal Fit }\end{array}$ & Good Fit \\
\hline 4. & NNFI & 0.90 & $\begin{array}{l}\geq 0.90 \\
0.80-0.89\end{array}$ & $\begin{array}{l}\text { Good Fit } \\
\text { Marginal Fit }\end{array}$ & Good Fit \\
\hline 5. & CFI & 0.95 & $\begin{array}{l}\geq 0.90 \\
0.80-0.89\end{array}$ & $\begin{array}{l}\text { Good Fit } \\
\text { Marginal Fit }\end{array}$ & Good Fit \\
\hline 6. & IFI & 0.92 & $\begin{array}{l}\geq 0.90 \\
0.80-0.89\end{array}$ & $\begin{array}{l}\text { Good Fit } \\
\text { Marginal Fit }\end{array}$ & Good Fit \\
\hline 7. & GFI & 0.90 & $\begin{array}{l}\geq 0.90 \\
0.80-0.89\end{array}$ & $\begin{array}{l}\text { Good Fit } \\
\text { Marginal Fit }\end{array}$ & Good Fit \\
\hline 8. & AGFI & 0.96 & $\begin{array}{l}\geq 0.90 \\
0.80-0.89\end{array}$ & $\begin{array}{l}\text { Good Fit } \\
\text { Marginal Fit }\end{array}$ & Good Fit \\
\hline
\end{tabular}

Based on Table 4. Goodness of Fit Index and the results of the analysis show that the overall model is good, so it can be continued in Absorptive Capacity Influence Analysis (AC) and Knowledge Sharing (KS) on SMEs performance with female business actors.

\subsection{Inferential Statistic : SEM}

This analysis was used to test the research hypothesis that had been determined by using the sample data obtained. The Inferential Statistics Method used in the analysis of this research data was SEM. The data obtained and the respondents used as the research samples through the distributed questionnaires would be analyzed by using SEM with Lisrel 8.70 program in obtaining the result of the path diagram and printed output. The output contained in the path diagram will inform the standardized solution which shows the loading factor, the value of the variance error indicating the error measurement parameter estimation, the standard error value that will be used to divide the parameter estimation value so that the obtained t-value and t-value indicate a significance.

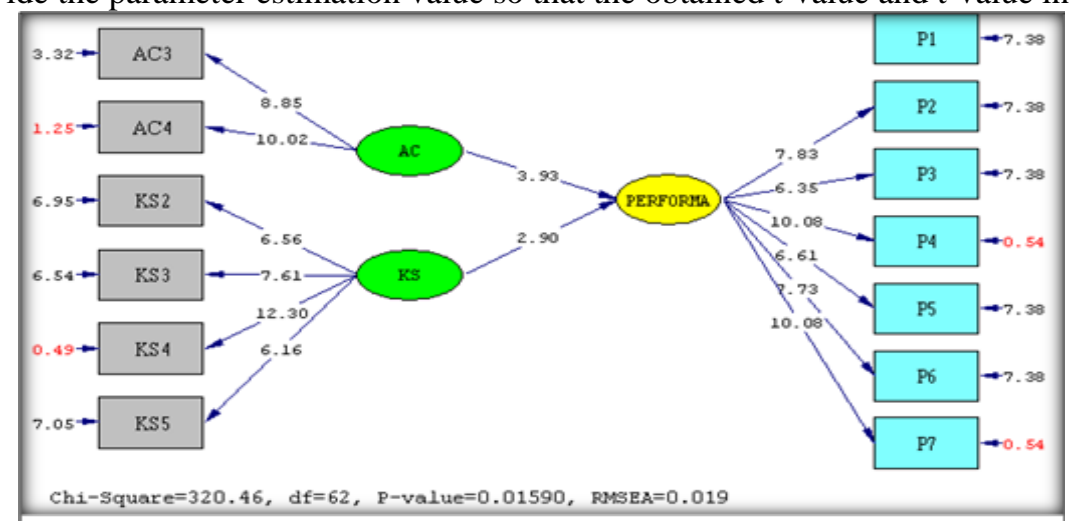

Figure 5.The Predicted Results of Full Model based on t-value

Based on Figure 5. it can be seen that the parameters in the Full Model were significant (the t-count value greater than 1.96), ie Absorptive Capacity (AC) on Performance and Knowledge Sharing (KS) on the Performance of Women-owned SMEs group incorporated in Alisah Khadijah ICMI Palembang, at the $0.05 \%$ level. The result of full model SEM analysis based on loading standard is shown in Figure 6: 


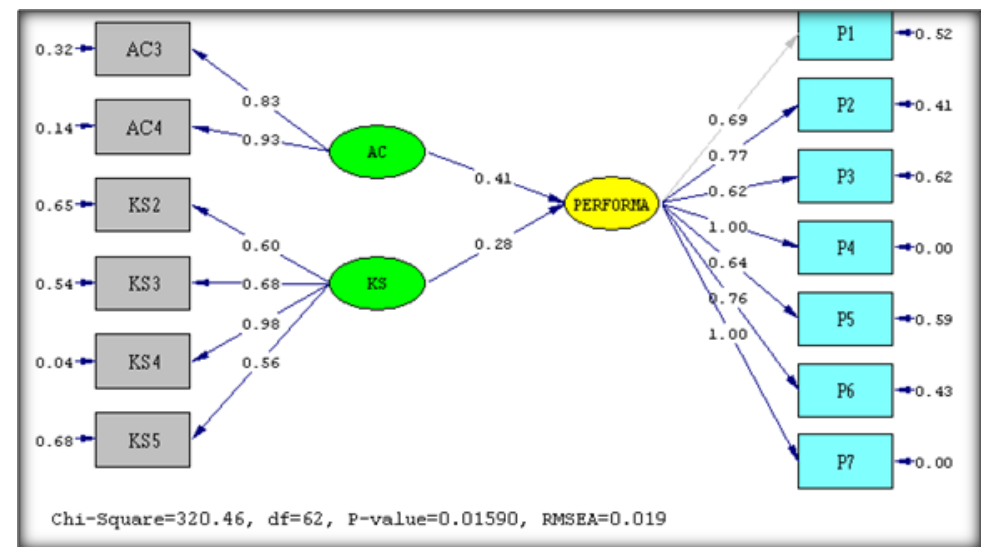

Figure 6.Basic Model Standardized Solution

Based on the above loading standard results, the following structural equation is obtained:

\section{Structural Equation:}

\section{PERFORMANCE $=0.41 * \mathrm{AC}+0.28 * \mathrm{KS}$}

Based on the structural model can be explained that Absorptive Capacity (AC) to Performance of women-owned SMEs group incorporated in Alisah Khadijah ICMI Palembang was 0.41, and Knowledge Sharing (KS) to Performance of women-owned SMEs group incorporated in Alisah Khadijah ICMI Palembang was equal to 0.28.

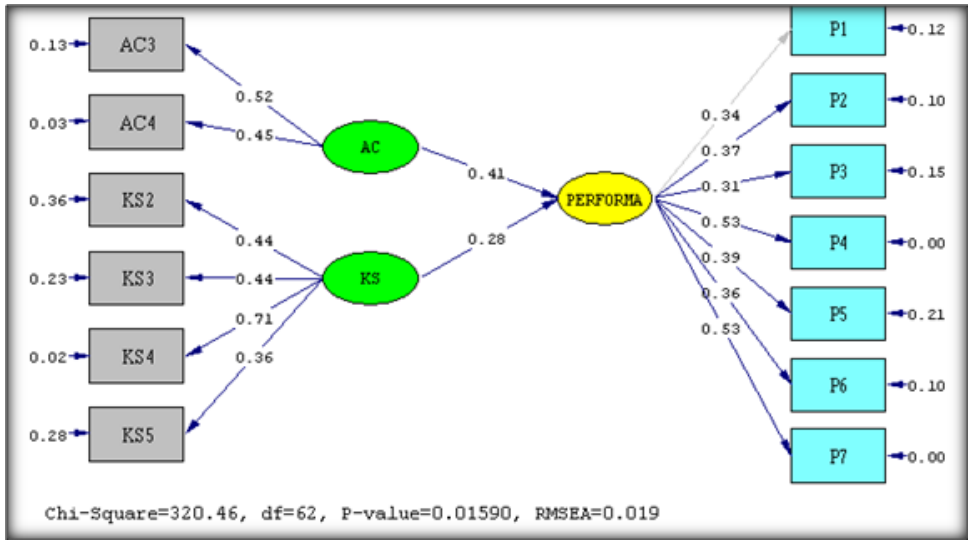

Figure7. Estimates Structure Model

Based on the results of hypothesis testing that has been performed, the researchers proved a significant relationship on the level of $95 \%$ confidence with t-values> 1.96 . Generally the results of hypothesis testing and estimation as in the following table:

Table 5. Hypothesis Test

\begin{tabular}{|l|l|l|l|l|}
\hline Hypothesis & Path & t-value & Estimation & Result \\
\hline $\mathrm{H}_{1}$ & AC $\rightarrow$ Performance & 3.93 & 0.41 & Accepted \\
\hline $\mathrm{H}_{2}$ & KS $\rightarrow$ Performance & 2.90 & 0.28 & Accepted \\
\hline
\end{tabular}

In Hypothesis 1, it can be seen from Table 5 that it was accepted because t-value was 3.93 (95\% confidence level)> 1,96 which means there was significant relation between Absorptive Capacity (AC) variable to Performance of women-owned SMEs group incorporated in Alisah Khadijah ICMI Palembang. Estimation value is shown in Table 5 of 0.41 which indicates that the influence of Absorptive Capacity (AC) variable had a positive and significant effect on Performance of women-owned SMEs group incorporated in Alisah Khadijah ICMI Palembang. Absorptive Capacity Process for SMEs Alisah Khadijah ICMI Palembang group also happens well because of the similarity of vision and mission so that the potential absorptive capacity and realized absorptive capacity can work synergistically and structurally. Coupled with the number of programs/business development activities that have been run or will be performed by Alisah Khadijah ICMI Palembang. 
In Hypothesis 2, it can be seen from Table 5 that it was accepted because t-value was 2.90 (95\% confidence level)> 1.96 which means there was a significant correlation between Knowledge Sharing (KS) variable to Performance of women-owned SMEs group incorporated in Alisah Khadijah ICMI Palembang. The estimated value is shown in Table 5 of 0.28 which indicates that the influence of Knowledge Sharing (KS) variables had a positive and significant effect on the Performance of women-owned SMEs group incorporated in Alisah Khadija ICMI Palembang. Thus, the behavior of knowledge sharing consists of donating knowledge and collecting knowledge occurs well in the women-owned SMEs group incorporated in Alisah Khadijah ICMI Palembang, which ultimately affects the improvement of business performance. The meetings, training/workshops and business discussions in the Whatsapp group and the telegram and other social media facilities among members of the Alisah Khadijah group of ICMI Palembang facilitate the breadth and depth of knowledge sharing process.

\section{Conclusion}

Based on the results of this study can be concluded as follows: 1. Absorptive Capacity (AC) and Knowledge Sharing (KS) had positive and significant influence on Performance of women-owned SMEs group incorporated in Alisah Khadijah ICMI Palembang. 2. Absorptive Capacity (AC) variable had more dominant influence on Performance of women-owned SMEs group incorporated in Alisah Khadijah ICMI Palembang compared to Knowledge Sharing (KS) variable. Further research should examine more deeply about the characteristics of women in doing Absorptive Capacity and Knowledge Sharing. In addition, it should include time intervals in the measurement of the influence of Absorptive Capacity and Knowledge Sharing in improving business performance. In addition, longitudinal studies are needed to provide more interesting results for the influence of Absorptive Capacity and Knowledge Sharing on business performance, because Absorptive Capacity and Knowledge Sharing are continuous learning process and declare business performance with quantitative measures of output and/or business turnover.

\section{REFERENCES}

Andrawina, L., Govindaraju, R., Samadhi, T. A., \& Sudirman, I. (2008). Hubungan Antara Knowledge Sharing Capability, Absorptive Capacity Dan Mekanisme Formal: Studi Kasus Industri Teknologi Informasi Dan Komunikasi Di Indonesia. Jurnal Teknik Industri, 10(2), 158-170. Retrieved from file://C:/Users/Acer/Downloads/16983-17584-1-PB.pdf

Basri, A. F. M., \& Rivai, V. (2005). Perfomance Appraisal. Jakarta: PT Raja Grafindo Persada.

Calantonea, R. J., Cavusgil, S. T., \& Zhao, Y. (2002). Learning Organization, Firm Innivation Capability and Firm Performance. Industrial Marketing Management, 31(6), 515-524. https://doi.org/10.1016/S0019-8501(01)00203-6

Cohen, W. M., \& Levinthal, D. A. (1990). Absorptive Capacity: A New Perspective on Learning and Innovation. Administrative Science Quarterly, 35(1), 128-152. https://doi.org/10.2307/2393553

Febrianty. (2017). Minat Pelaku UKM Atas Pilihan Untuk Penerapan Strategi Koopetisi (Studi Kasus : UKM di Kota Palembang). In Seminar Nasional Teknologi Informasi, Bisnis, dan Desain (pp. 34-42). Palembang: STMIK - Politeknik PalComTech. Retrieved from http://www.news.palcomtech.com/wp-content/uploads/downloads/2017/08/05_FEBRIANTY.pdf

Febrianty, \& Divianto. (2017). THE INFLUENCE OF ENTREPRENEURIAL ACTION GROUP ON THE SMES PERFORMANCE THROUGH INTERNALIZATION OF QUADRUPLE HELIX INNOVATION ROLE. Biotika, 2(15), 30-41. Retrieved from https://journal-biotika.com/current-issues/2017-02/article_07.pdf

Ferdinand, A., T. (2005). Structural Equation Modelling. Semarang, Indonesia: Badan Penerbit Universitas Diponegoro.

Hadiwijaya, H. (2015). Pengaruh Gaya Kepemimpinan dan Motivasi Terhadap Kinerja Karyawan Pada Unit Usaha Pengembangan dan Lingkungan PT. Perkebunan Mitra Ogan Baturaja. Jurnal Ekonomi Dan Informasi Akuntansi (Jenius), 5(1), 37-56.

Hadiwijaya, H. (2017). Analisis Organization Citizenship Behavior (Ocb) Dan Person Organization Fit(Po-Fit) Terhadap Kinerja Karyawan Bagian Non Medis Rumah Sakit Islam Siti Khodijah Palembang. Jurnal MOTIVASI, 2(1), $188-199$.

Hooff, V. D., \& Ridder, J. . (2004). Knowledge Sharing in Context: The influence of Organizational Commitment, Communication Climate and CMC use on Knowledge Sharing. Journal of Knowledge Management, 11(1), 13-24.

Hooff, B. van den, \& Weenen, F. de L. van. (2004). Committed to Share: Commitment and CMC Use as Antecedents of Knowledge sharing. Knowledge and Process Management, 11(1), 13-24. https://doi.org/10.1002/kpm.187

Mathis, R. L., \& Jackson, J. H. (2006). Manajemen Sumber Daya Manusia. Jakarta: Salemba Empat.

Mathuramaytha, C. (2012). Developing Knowledge-Sharing Capabilities Influence Innovation Capabilities in Organizations - a Theoretical Mode. In nternational Conference on Education and Management Innovation IPEDR vol.30 (pp. 285-291). Singapore: IACSIT Press.

Matzler, K., \& Mueller, J. (2011). Antecedents of knowledge sharing - Examining the influence of learning and performance orientation. Journal of Economic Psychology, 32(3), 317-329.

Nonaka, I., \& Takaeuchi, H. (1995). The Knowledge-Creating Company. New York: Oxford University Press.

Prawirosentono, S. (2001). Manajemen Operasional : Analisis dan Studi Kasus (2nd ed.). Jakarta: PT Bumi Aksara.

Umar, H. (2008). Metode Riset Bisnis. Jakarta: PT Gramedia Pustaka Utama.

Wang, S., \& A. Noe, R. (2010). Knowledge sharing: A review and directions for future research. Human Resource Management 
Review, 20(2), 115-131. https://doi.org/10.1016/j.hrmr.2009.10.001

Zahra, S. A., \& George, G. (2002). Absorptive Capacity: A Review, Reconceptualization, and Extension. The Academy of Management Review, 27(2), 185-203. https://doi.org/10.2307/4134351 